\title{
Dairy progeny testing in Finland ${ }^{1}$ )
}

\author{
Ulf Lindström${ }^{2}$ ) and Kalle Maijala \\ Agricultural Research Centre, Institute of Animal Breeding, Tikkurila \\ Мikко VARo \\ University of Helsinki, Department of Animal Breeding, Viikki
}

Received March 9, 1973

\begin{abstract}
An account is given of the present method of progeny testing of dairy bulls. Correction factors used are presented and an example of their application given. It is noted that progeny tests for milk yield based on less than 30 daughters have a low repeatability. There were no significant changes in the ranking order of AI bulls in different geographical areas. In the Ostrobothnia area, however, the progeny tests seemed to be slightly less accurate than in other regions.
\end{abstract}

Our present method of progeny testing of bulls for dairy characters is based on a method developed by $\mathrm{prof}$. M i k k o V a r o. Progeny testing of bulls in Finland was done according to this method already in 1950. A description of the principles is given by VARo (1958) and Lindström (1969).

In the course of time the method has been modified at the Department of Animal Breeding in collaboration with the AI and breeding organisations. Nowadays the progeny tests are computed at the Central Association of AI Societies. Previously (up to 1963) the Department of Animal Breeding of the Agric. Research Centre did the calculations.

\section{Material}

All figures used in the calculations stem from the reports given by the milk recorders. Previously the material needed for the progeny tests was collected once a year, at the termination of the recording year. Today the monthly reports sent by the recorders to the data processing department are automatically stored on magnetic tapes or discs. This makes it possible to

1) Paper presented by dr. Lindström at the 2nd World Ayrshire Conference, Lahti, August 3, 1972.

${ }^{2}$ ) At present at the Department of Animal Production, University of Nairobi, Kenya. 
calculate the progeny tests more often, even once a month if desired. So far the progeny tests have been based on the results of the recording year. Recently, however, a method has been adopted whereby the production of the daughters is also given as a 12 month rolling average. This enables us to use all records and to speed up the computations.

Only the results for daughters milking their first, second or third recording year are included. A minimum of 10 daughters per sire is required before a progeny test is calculated.

\section{Corrections}

In order to account for the environmental influences within herds, each daughter's milk and fat production result is compared with the corresponding herd average. The daughter's own result is included in the herd average. This is a safety measure as our recorded herds, on an average, consist of only 7 cows. The daughter's result in per cents of the herd average is called her relative production. When more than one breed is represented in a herd, separate averages for the breeds in question are computed. (Minimum 2 cows required.) These are used when calculating the relative production. The fat $\%$ is calculated as a deviation from the herd average (including the daughter).

To account for differences in a ge and $\mathrm{month}$ of $\mathrm{calving}$ of the daughters corrections are made. From $\mathrm{T}$ a b le 1 it appears that especially the time of calving affects the milk production results to a high degree. The fat percentage, on the other hand, is but slightly affected by these systematic influences.

\section{Calculation of progeny test}

Each year (or each time the progeny test is calculated) correction factors for the effects of age and calving month are computed by least squares procedures (see Table 1). The correction factors used when calculating the

Table 1. Influence of age and calving month on the 3 first production years of Ayrshire cows (recording year 1967/68, least squares analysis ${ }^{1}$ ).

\begin{tabular}{|c|c|c|c|c|c|}
\hline \multirow[b]{2}{*}{ Production year } & \multirow{2}{*}{$\begin{array}{c}\text { Number } \\
\text { of } \\
\text { records }\end{array}$} & \multicolumn{4}{|c|}{ Percentage of total variation } \\
\hline & & $\begin{array}{c}\text { Relati } \\
\text { age }\end{array}$ & $\begin{array}{l}\text { ve milk prod. } \\
\text { calv. month }\end{array}$ & $\begin{array}{l}\text { Fat } \% \\
\text { age }\end{array}$ & $\begin{array}{l}\text { deviat. } \\
\text { calv. month }\end{array}$ \\
\hline First .............................. & 29523 & 1.66 & 9.49 & 0.44 & 0.81 \\
\hline 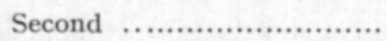 & 22452 & 0.47 & 3.10 & 0.07 & 0.44 \\
\hline 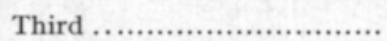 & 19779 & 0.18 & 3.13 & $\left.0.00 \mathrm{~ns}^{2}\right)$ & 0.66 \\
\hline
\end{tabular}

1) Least squares analysis means that the influences of age and calving month have $\mathrm{sim} \mathrm{u} 1 \mathrm{t}$ a n e u s l y been considered (HARveY 1966). In other words, the age influence is free from the effect of calving month and vice versa. (Statistically speaking we obtain u n b i a s e d estimates of these influences.)

$\left.{ }^{2}\right)$ ns $=$ not statistically significant; all other figures highly significant. 
progeny test in May 1972 are given in T a b l e 2. The procedure in calculating the progeny test is perhaps most easily explained by an example. Let us assume that an individual daughter of a certain bull is born in June 1968, that she is milking her first year, that she has calved in July and that her relative production is 91.7. From Table 2 we note that the average relative production for a cow of this age is 90.5 . Further we note that cows milking their first year and calving in July are $-\mathbf{5 . 8}$ relative units below the overall average. The result for this daughter is thus as follows: $91.7-(90.5$ -5.8 ), i.e. $91.7-90.5+5.8$ or 7.0 . In other words, this cow is $7 \%$ above other Ayrshire cows of the same age calving at the same time.

Table 2. Correction for effect of age and calving month in Ayrshire (recording year 1971/72; results for latest 12 months production).

a. Least squares estimates of the age effect.

\begin{tabular}{|c|c|c|c|}
\hline Cow & born; month, year & Rel.milk.prod. & Fat $\%$ deviat. \\
\hline \multirow[t]{11}{*}{$1 \mathrm{st}$} & prod. year & & \\
\hline & $\begin{array}{l}6,69 \\
4,69\end{array}$ & $\begin{array}{l}83.2 \\
85.1\end{array}$ & $\begin{array}{l}0,4 \\
0.4\end{array}$ \\
\hline & $\begin{array}{l}4,69 \\
2,69\end{array}$ & 86.5 & 0.6 \\
\hline & $\begin{array}{r}2,69 \\
11,68\end{array}$ & 88.1 & 0.6 \\
\hline & $\begin{array}{l}11,68 \\
10,68\end{array}$ & 89.9 & 0.6 \\
\hline & $\begin{array}{r}10,68 \\
8,68\end{array}$ & 90.5 & 0.6 \\
\hline & $\begin{array}{l}8,68 \\
6,68\end{array}$ & 91.3 & 0.9 \\
\hline & $\begin{array}{l}6,68 \\
4,68\end{array}$ & 91.4 & 1.1 \\
\hline & $\begin{array}{l}4,68 \\
2,68\end{array}$ & 91.1 & 0.9 \\
\hline & $\begin{array}{r}2,68 \\
12,67\end{array}$ & 93.1 aver. 89.0 & 0.7 aver. 0.67 \\
\hline & & & \\
\hline \multicolumn{4}{|c|}{$2 \mathrm{nd}$ prod. year } \\
\hline & 8,68 & 90.3 & 0.7 \\
\hline & 6,68 & 93.6 & 0.5 \\
\hline & 4,68 & 93.2 & 0.8 \\
\hline & 2,68 & 93.8 & 0.7 \\
\hline & 12,67 & 95.1 & 0.6 \\
\hline & 10,67 & 96.7 & 0.6 \\
\hline & 8,67 & 96.9 & 0.5 \\
\hline & 6,67 & 97.2 & 0.5 \\
\hline & 4,67 & 96.6 & 0.7 \\
\hline & 2,67 & 98.0 aver. 95.1 & 0.4 aver. 0.59 \\
\hline \multicolumn{4}{|c|}{$3 \mathrm{rd}$ prod. year } \\
\hline & 8,67 & 97.0 & 0.4 \\
\hline & $6,67:$ & 97.3 & 0.6 \\
\hline & 4,67 & 98.1 & 0.5 \\
\hline & 2,67 & 98.5 & 0.4 \\
\hline & 12,66 & 99.7 & 0.2 \\
\hline & 10,66 & 100.9 & 0.3 \\
\hline & 8,66 & 101.8 & 0.2 \\
\hline & 6,66 & 101.3 & 0.2 \\
\hline$\cdots$ & 4,66 & 101.2 aver. 99.4 & 0.2 aver. 0.24 \\
\hline
\end{tabular}


b. Least squares constants (deviations from overall average) for the calving month effect.

\begin{tabular}{rrrrrrr}
\hline $\begin{array}{c}\text { Calving } \\
\text { month }\end{array}$ & $\begin{array}{c}\text { Production year } \\
\text { rel.milk } \\
\text { yield }\end{array}$ & $\begin{array}{c}\text { 1st } \\
\text { fat } \% \\
\text { dev. }\end{array}$ & $\begin{array}{c}\text { rel.milk } \\
\text { yield }\end{array}$ & $\begin{array}{c}\text { fnd } \% \\
\text { dev. }\end{array}$ & $\begin{array}{c}\text { rel.milk } \\
\text { yield }\end{array}$ & $\begin{array}{c}\text { 3rd } \\
\text { fat } \% \\
\text { dev. }\end{array}$ \\
\hline & & & & & & \\
1 & 2.1 & 0.1 & -1.6 & -0.2 & -1.3 & -0.1 \\
2 & -0.0 & 0.3 & -3.1 & -0.1 & -1.8 & -0.1 \\
3 & -1.1 & 0.3 & -1.0 & -0.1 & 1.2 & -0.2 \\
4 & -2.7 & 0.3 & -0.2 & -0.2 & 1.5 & -0.2 \\
5 & -6.3 & 0.3 & -1.9 & 0.1 & -0.8 & -0.2 \\
6 & -7.8 & -0.0 & -2.1 & 0.2 & -1.8 & 0.1 \\
7 & -5.8 & -0.6 & -0.1 & -0.0 & -1.0 & 0.1 \\
8 & 1.0 & -0.3 & 1.6 & 0.0 & 0.2 & -0.1 \\
9 & 4.8 & 0.0 & 3.4 & 0.2 & 1.3 & 0.4 \\
10 & 6.3 & -0.1 & 3.3 & 0.1 & 1.8 & 0.3 \\
11 & 5.1 & -0.0 & 1.9 & 0.1 & 1.5 & 0.1 \\
12 & 4.4 & -0.2 & -0.1 & -0.1 & -0.8 & -0.1 \\
\hline
\end{tabular}

The calculations and the results for all daughters of the sire are done similarly. The results with regard to fat $\%$ deviation, $4 \%$ milk production, fat $\mathrm{kg}$ production and live weight deviation can be calculated in the same way.

\section{Correction for no. of daughters}

The milk production figures are corrected for the number of daughters the test is based on. This is done by multiplying the average relative yield by the regression factor $n /(n+15)$, where $n=$ no. of daughters. For example, when the test is based on 20 daughters the correction factor is 0.57 , on 100 daughters it is 0.87 . Let us assume that a sire has been tested on $\mathbf{4 5}$ daughters, the average relative production being +4.8 units. Thus the corrected relative production is $45 /(45+15) \times 4.8=0.75 \times 4.8=3.6$. In other words, we could expect the next progeny test (based on an infinite number of daughters) of this sire to be +3.6 units above average. The fat $\%$ deviation is not corrected because it is quite repeatable.

\section{Use of progeny test results}

The most important task of the progeny tests is to provide a basis for the selection of bull sires and sordinary" sires for production of female replacements. Each time the progeny test is calculated the State AI Committee (consisting of representatives from research, AI and breeding sectors, Ministry of Agriculture, Veterinary Medicine) meets and selects the sires on the basis of test results and the amount of pellets stored.

The Breed Society classifies the bulls in breeding and elite classes according to test results. At present the selection criterion used when picking the 
bulls is the so called combined deviation. This is made up of the corrected relative production plus 10 times the fat percentage deviation. The combined deviation gives approximately correct economic weights to milk production and fat percentage under our present conditions (LINDSTRöM and Maijala 1971). In practice this means that the main emphasis is on milk yield, while the fat percentage will be kept approximately at the present level. The Appendix gives a list of the information included in the progeny test.

\section{Improving the accuracy}

Because of our small herds the accuracy ot progeny tests based on small numbers of daughters is low. This is evident from $\mathrm{T} \mathrm{a} \mathrm{ble} 3$. (The reason why the repeatability for some of the progeny tests based on more than 50 daughters also is low is probably to be found in the 1968 test which was based on a small number of daughters.) It would seem that at least 40 daughters, and preferably $60-80$, would be needed to give a satisfactory degree of accuracy.

Table 3. Repeatability of Ayrshire progeny tests for relative milk yield (Progeny tests corrected for age and month of calving; only first year records used.)

\begin{tabular}{ccc}
\hline $\begin{array}{c}\text { No. of daughters in } 1967 \\
\text { progeny test }\end{array}$ & No. of bulls & $\begin{array}{c}\text { Correlation to } 1968 \text { pro- } \\
\text { geny test, } \%\end{array}$ \\
\hline 20 & 59 & 48.2 \\
$21-30$ & 67 & 47.9 \\
$31-40$ & 59 & 69.1 \\
$41-50$ & 40 & 77.6 \\
$51-70$ & 62 & 50.9 \\
$71-100$ & 43 & 77,1 \\
$\geqq 100$ & 43 & 65.2 \\
\hline
\end{tabular}

The most effective way of improving the overall accuracy would probably be to calculate corrected herd averages. That is, before the herd average is computed the records for each cow in the herd would be corrected with regard to age and calving month. Moreover, it would be preferable to take into account the progeny test of the sire of each cow (LINDSTRÖM and MaIJALA 1972). In this way it would be possible to eliminate at least some of the inaccuracies due to the varying composition of our small herds.

\section{Differences between areas}

Do progeny tests in one geographical area satisfactorily indicate a bull's breeding value in another area? This question has recently been investigated. 
Table 4. Association between progeny tests for the same Ayrshire AI-bulls in different geographical areas (Recording year 1970/71 results).

\begin{tabular}{|c|c|c|c|c|c|c|c|c|}
\hline & \multirow{3}{*}{\multicolumn{2}{|c|}{ Areas $\left.^{1}\right)$}} & \multirow{3}{*}{$\begin{array}{l}\text { No. of } \\
\text { bulls }\end{array}$} & \multirow{2}{*}{\multicolumn{2}{|c|}{$\begin{array}{c}\text { Aver. no. } \\
\text { of daughters }\end{array}$}} & \multicolumn{3}{|c|}{ Genetic correlation, $\%^{2}$ ) } \\
\hline & & & & & & rel.milk & fat $\%$ & rel.fat \\
\hline & & & & N 1 & N 2 & yield & dev. & kg yield \\
\hline SF & $\times \mathrm{CF}$ & .............. & 68 & 117 & 38 & 101 & 101 & 106 \\
\hline SF & $\times$ Ostr. & ............... & 69 & 91 & 33 & 86 & 96 & 92 \\
\hline CF & $\times \mathrm{NF}$. & .............. & 41 & 90 & 16 & 107 & 103 & 114 \\
\hline \multirow[t]{2}{*}{ Ostr. } & $\times$ NF. & .............. & 27 & 92 & 21 & 81 & 93 & 110 \\
\hline & & & & \multicolumn{2}{|c|}{ Average } & 94 & 98 & 105 \\
\hline
\end{tabular}
1) $\mathrm{SF}=$ Southern Finland,
$\mathrm{CF}=$ Central Finland
Ostr. = Ostrobothnia,
$\mathrm{NF}=$ Northern Finland

$\left.{ }^{2}\right)$ Genetic correlations $\left(r_{G}\right)$ calculated from: $r_{G}=\frac{r_{P_{1} P_{2}}}{\sqrt{b_{1} \times b_{2}}}$,

where $\mathrm{r}_{\mathrm{P}_{1} \mathrm{P}_{2}}=$ phenotypic correlation between progeny test results in area 1 and 2 $b_{1}$ and $b_{2}=$ repeatability of progeny tests in area 1 and 2 (calculated from the number of daughters, assuming a heritability of 0.2 for one record, LINDSTRÖM 1969).

The main results are given in $\mathrm{T}$ a ble 4 . The ranking order of the bulls is not affected to a noticeable degree. (Due to the method of calculation some of the correlations exceed $100 \%$ ). It seems, however, that the progeny tests in the Ostrobothnia area are somewhat less accurate indicators of a bulls value than progeny tests in other areas. The progeny tests here were calculated using correction factors (for age and calving month) applicable to the respective areas. It might be useful to include this procedure also in the routine progeny testing as there seem to be differences between the areas in this respect.

\section{REFERENCES}

HARVEY, W. R. 1966. Least squares analysis of data with unequal subclass number. ARS 20-8. Agr.Res. Service. US Dep. of Agr. 157 pp.

LiNDSTRÖM, U. B. 1969. Genetic change in milk yield and fat percentage in artificially bred populations of Finnish dairy cattle. Acta Agr. Fenn. 114.

- - \& Maijala, K. 1971. Studies on AI dairy sire provings. I. Importance of various recordecd characteristics. Z. Tierz. zücht. biol. 87: 292-298.

- $-\&$ MaijalA, K. 1972. Improving accuracy of bull dam selection. Acta Agr. Scand. 22: $189-199$.

VARo, M. 1958. Uber die brauchbarkeit unserer Bullewerte auf den verschiedenen Leistungsstufen. Acta Agr. Fenn. 93(4): 1-31. 


\title{
Sonnien jälkeläisarvostelu Suomessa ${ }^{1}$ )
}

\author{
Ulf Lindström ja Kalle Maijala
}

Maatalouden tutkimuskeskus, Kotieläinjalostuslaitos, Tikkurila

\section{MIKKo VARo \\ Helsingin yliopisto, Kotieläinten jalostustieteen laitos, Viikki}

Karjantarkkailun tuloksiin perustuvan sonnien jälkeläisarvostelun laskenta automaattisella tietojenkäsittelyllä aloitettiin v. 1950. Periaatteessa samanlaisena pysyneeseen laskentamenettelyyn on tehty eräitä täydennyksiä. Nykyisin arvostelu lasketaan jälkeläisten kolmen ensimmäisen tuotoksen perusteella käyttämällä suhteellisia tuotoksia tuotantokyvyn mittana. Tuotokset korjataan iän, tuotosvuoden ja poikimiskuukauden mukaan sekä lopullinen arvostelu jälkeläisten luvun mukaan. Kaikki sonnit, joilla on vähintään 10 jälkeläistä, arvostellaan.

Arvostelun luotettavuuden arvioimiseksi on laskettu eri suurten jälkeläisryhmien ensimmäisiin tuotoksiin perustuvien jälkeläisarvojen toistumiskertoimia. Tulos viittaa siihen, ettå vasta vähintään 40 , mieluummin $60-80$ jälkeläistä riittää tyydyttävän luotettavaan arvosteluun.

1) Esitelmä, jonka tohtori Lindström piti Maailman 2. Ayrshirekonferenssissa Lahdessa 3. 8. 1972 . 


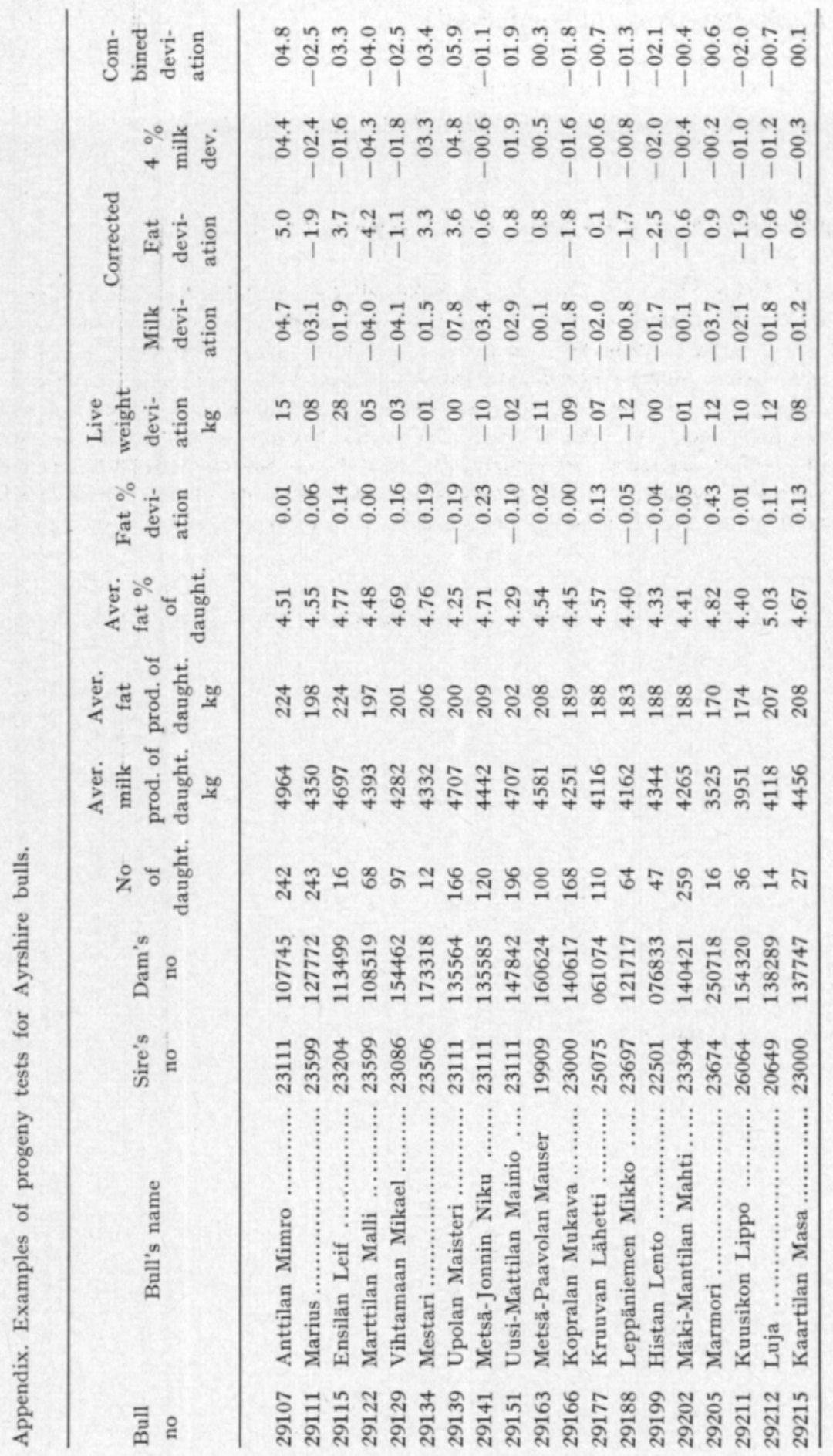

